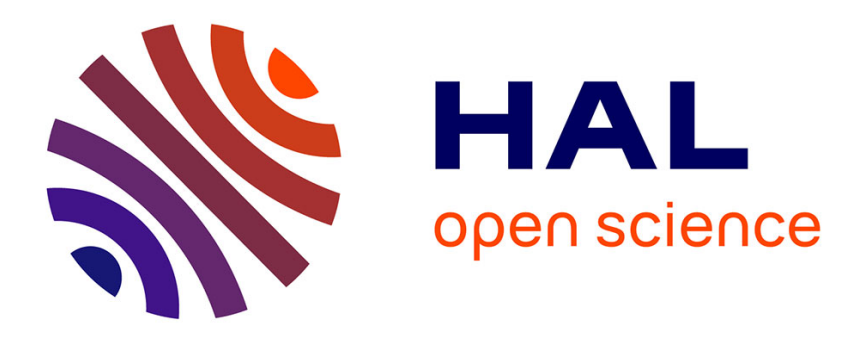

\title{
Damaging effects of household cleaning products on the lungs
}

\author{
Orianne Dumas, Nicole Le Moual
}

\section{To cite this version:}

Orianne Dumas, Nicole Le Moual. Damaging effects of household cleaning products on the lungs. Expert Review of Respiratory Medicine, 2020, 14 (1), pp.1-4. 10.1080/17476348.2020.1689123 . inserm02468489

\section{HAL Id: inserm-02468489 https://www.hal.inserm.fr/inserm-02468489}

Submitted on 5 Feb 2020

HAL is a multi-disciplinary open access archive for the deposit and dissemination of scientific research documents, whether they are published or not. The documents may come from teaching and research institutions in France or abroad, or from public or private research centers.
L'archive ouverte pluridisciplinaire HAL, est destinée au dépôt et à la diffusion de documents scientifiques de niveau recherche, publiés ou non, émanant des établissements d'enseignement et de recherche français ou étrangers, des laboratoires publics ou privés. 


\section{Damaging effects of household cleaning products on the lungs}

Orianne Dumas ${ }^{1,2}$ and Nicole Le Moual ${ }^{1,2}$

${ }^{1}$ Inserm, U1168, VIMA: Aging and chronic diseases. Epidemiological and public health approaches, F-94807, Villejuif, France

${ }^{2}$ Univ Versailles St-Quentin-en-Yvelines, UMR-S 1168, F-78180, Montigny le Bretonneux, France

\section{Correspondance}

Orianne Dumas

Inserm UMR-S 1168 - VIMA

Vieillissement et maladies chroniques. Approches épidémiologique et de santé publique.

16, avenue Paul Vaillant Couturier

94807 Villejuif cedex

France

e-mail: orianne.dumas@inserm.fr

Tel: (33) 145595357

Key words: Cleaning products; Disinfectants; Asthma; COPD; Chemical exposures

Funding: This paper was not funded.

Declaration of interest: The authors have no relevant affiliations or financial involvement with any organization or entity with a financial interest in or financial conflict with the subject matter or materials discussed in the manuscript. This includes employment, consultancies, honoraria, stock ownership or options, expert testimony, grants or patents received or pending, or royalties. 
Cleaning products and disinfectants are important contributors to chemical exposures in the indoor environment. Concerns regarding their health effects, which may range from fertility to cardiovascular and respiratory disorders, have been growing in the last two decades [1-4]. Adverse respiratory effects of cleaning products were first observed in populations experiencing high level of exposure at the workplace, such as cleaners and healthcare workers, with a primary focus on asthma [1,5]. Cleaning products are also commonly used in private homes. Our editorial provides an overview of the recent epidemiological literature on the respiratory health effects associated with these exposures - which impacts adults as well as children - and discusses challenges and opportunities for future research on this question.

\section{Respiratory effects of cleaning products in adults: from asthma to COPD}

An association between weekly use of cleaning sprays at home and asthma incidence in adults was first reported in 2007 [6], based on a longitudinal analysis of the European Community Respiratory Health Survey (ECRHS). This analysis suggested a population attributable fraction of $\sim 15 \%$ in adult asthma for weekly use of sprays. Consistent findings were observed in a recent longitudinal study of young adults in Germany [7]. Exposure was characterized by two separate composite scores, based on the frequency of use of 9 types of sprays and 6 types of disinfectants. High use of disinfectants was significantly associated with increased risk of incident asthma, and a similar tendency was suggested for high use of sprays. Both studies used standardized and validated definitions for asthma. Associations between domestic use of cleaning products and additional asthma outcomes have been reported in the French Epidemiological Study of the Genetics and Environment of Asthma (EGEA). Specifically, the use of cleaning sprays at home was associated with poor asthma control (evaluated according to international guidelines) [8] and higher exhaled nitric oxide fraction (FeNO), a marker of eosinophilic airway inflammation [9], while the use of bleach was 
associated with non-allergic asthma [10]. These latter findings are consistent with results from occupational studies and suggest that different cleaning agents, which can be sensitizers or airway irritants [1,11], are associated with specific asthma phenotypes through different mechanisms.

The irritant properties of many chemicals contained in cleaning products [1] have prompted research on respiratory effects beyond asthma. Inhalation of irritants may indeed cause injury of the airway epithelium, oxidative stress and neutrophilic airway inflammation $[12,13]$, which are also relevant to Chronic Obstructive Pulmonary Disease (COPD) pathogenesis. In cleaning workers, a higher risk of COPD or chronic bronchitis $[14,15]$ and higher rates of death due to COPD [16] have been reported. In a cohort study of 73262 US female nurses, occupational exposure to cleaning products and disinfectants was significantly associated with an increased risk of developing COPD, independent of asthma (i.e., the association was observed among participants both with and without asthma). High-level exposure, evaluated by a job-task-exposure matrix, to several specific disinfectants (ie, glutaraldehyde, bleach, hydrogen peroxide, alcohol, and quaternary ammonium compounds) was significantly associated with COPD incidence [17]. However, this study did not investigate the impact of household exposures.

An impact of exposure to cleaning products on lung function outcomes has also been observed. In the latest longitudinal analysis of the ECRHS (population-based study), using new follow-up data, exposure to cleaning activities either at work or at home was associated with accelerated $\mathrm{FEV}_{1}$ and FVC decline [18]. This result was observed in women only and independent of asthma. No association was observed between cleaning activities and $\mathrm{FEV}_{1} / \mathrm{FVC}$ decline or airway obstruction, but the latter analysis was limited by a small number of cases $[18,19]$. Similarly, use of cleaning sprays at home was associated with poorer lung function among participants both with and without asthma in the French EGEA study [9]. 


\section{Respiratory effects of cleaning products in children: the importance of early life exposures}

In the last decade, exposure to household cleaning products has also emerged as a risk factor for respiratory disorders in childhood. The strongest evidence, based on results from several large European birth cohorts [20-23], was found for an association between exposure to cleaning products either during pregnancy or during the first years of life, and persistent wheezing in early childhood. These studies evaluated exposure to cleaning products using composite scores for the use of household chemicals, cleaning products or sprays, and adjusted for a number of potential confounders including host factors (eg, maternal/paternal history of asthma/allergies), prenatal exposures (e.g., maternal smoking), birth outcomes (e.g., preterm delivery, C-section), early-life exposures (e.g., breastfeeding, environmental tobacco smoke, parental socio-economic status, daycare attendance), or other household exposures (e.g., pet ownership, siblings, characteristics of dwelling). An association between early life exposure to cleaning products at home and lower lung function parameters, as well as higher FeNO, has also been suggested in children [20,24]. In contrast with early-life exposure, the potential impact of exposure during later childhood or adolescence on asthma remains unclear. In a recent cross-sectional analysis of the PIAMA birth cohort using data from 14-years old participants, no association was observed between use of household cleaning agents and asthma [25].

These results suggest that both timing and level of exposure are important factors to understand a potential causal effect of household cleaning products on respiratory health. In accordance with Developmental Origins of Health and Disease (DOHaD) concept, exposure in early life, a period of increased susceptibility, may be of particular concern. Moreover, the time spent indoor - and by extension potential level of exposure to cleaning products - is particularly high in the first years of life. This supports the investigation of exposure to cleaning products 
in other common early-life indoor environments, such as daycares, where cleaning is performed frequently [26]. In older populations, it has been suggested that subjects using the products themselves are at higher risk than those passively exposed [27]. This may explain the absence of association between household exposure to cleaning products and asthma among adolescents [25], who are unlikely to perform cleaning tasks at home, although this result needs to be confirmed in further studies.

\section{Challenges and opportunities in assessing causative agents and mechanisms}

Despite accumulating evidence for adverse respiratory effects of household cleaning products, specific tasks and substances at risk still need to be elucidated. Household cleaning implies various tasks and the use of many chemicals, and the investigation of their health effects raise several issues. First, exposure data are limited, in particular quantitative exposure assessments. It is particularly challenging to accurately assess exposure to many substances in epidemiological studies. Studies have generally used questionnaires, which is prone to both differential and non-differential misclassification errors, as participants are unlikely to know the detailed composition of the products they use. To overcome this issue, a new method using a smartphone application to scan the cleaning products' bar code, with a related database linking the bar codes to the products' compositions, has been proposed [28]. This method could be particularly useful in large populations, in which quantitative exposure measurements are hardly feasible. Development of biomarkers of exposure to cleaning products and disinfectants, as well as exposure modelling studies are also needed [29]. A second challenge is to disentangle the mutual effect of the numerous chemicals contained in cleaning products, as well as their mixture [2]. Data-reduction approaches, e.g. using clustering models to identify exposure patterns, have been proposed to take into account the multiplicity and correlations of exposures [30,31]. Methods developed in the context of exposome research [32] are also of interest to 
address these questions. Finally, several studies have suggested a "healthy home cleaning effect" (similar to a "healthy worker effect" in occupational studies), i.e. an avoidance or a reduction in use of some cleaning products related to respiratory symptoms $[7,8]$. This potential effect should be anticipated when conducting epidemiological studies, as it may bias associations towards the null. Collecting longitudinal data with repeated assessment of both exposure and respiratory outcomes, and using adapted modelling [33] is recommended to control for this potential bias.

Mechanisms underlying the association between exposure to cleaning products and respiratory health outcomes remain poorly understood [1]. Cleaning products and disinfectants are likely to have a direct effect on the airways through inhalation of low molecular weight allergens or airway irritants. A recent study on the impact of exposure to laundry detergents on human bronchial epithelial cells supported a direct disruptive effect on the epithelial barrier integrity [34]. This mechanism may be relevant for other household cleaning products [34], but toxicological research on these specific products is needed. In future epidemiological studies on asthma, it appears critical to consider the disease heterogeneity by incorporating information not only on allergic status, but on a broader range of clinical characteristics and relevant biomarkers (e.g., inflammation and oxidative stress-related markers [35]). New interesting hypotheses regarding mechanisms also include a role of the microbiome. Cleaning and disinfection products, which aim at removing or inactivating microorganisms, are likely to influence indoor environmental microbiota, and possibly gut or airway microbiota [36,37]. In a Canadian birth cohort, the use of disinfectants or eco-friendly products for home cleaning was associated with significant differences in infants' gut microbiota composition [36]. These differences partly mediated an association between exposure to disinfectants and higher BMI at age 3 years. In the context of a gut-lung axis, gut microbiota is also relevant in asthma pathogenesis [38]. Finally, there is increasing evidence that chemical exposures, especially in 
early-life, may be associated with epigenetic alterations [39]. This potential mechanism is relevant for the effect of cleaning products and should be examined [34].

\section{Conclusion}

There is now strong epidemiological evidence for an adverse effect of exposure to cleaning products and disinfectants on respiratory health, not only in adults with high level of exposure at work, but also in relation to common household exposures, in particular during periods of increased susceptibility such as the early-life. While more research is needed to precisely identify causative agents and mechanisms, reduction in exposure and development of safer methods for home cleaning is recommended. 


\section{References}

[1] Folletti I, Siracusa A, Paolocci G. Update on asthma and cleaning agents. Curr. Opin. Allergy Clin. Immunol. 2017;17:90-95.

[2] Siracusa A, De Blay F, Folletti I, et al. Asthma and exposure to cleaning products - a European Academy of Allergy and Clinical Immunology task force consensus statement. Allergy. 2013;68:1532-1545.

[3] Gaskins AJ, Chavarro JE, Rich-Edwards JW, et al. Occupational use of high-level disinfectants and fecundity among nurses. Scand. J. Work. Environ. Heal. 2017;43:171-180.

[4] Mehta AJ, Adam M, Schaffner E, et al. Heart Rate Variability in Association with Frequent Use of Household Sprays and Scented Products in SAPALDIA. Env. Heal. Perspect. 2012;120:958-964.

[5] Dumas O, Wiley AS, Quinot C, et al. Occupational exposure to disinfectants and asthma control in US nurses. Eur. Respir. J. 2017;50:pii: 1700237.

[6] Zock JP, Plana E, Jarvis D, et al. The use of household cleaning sprays and adult asthma: an international longitudinal study. Am J Respir Crit Care Med. 2007;176:735-741.

[7] Weinmann T, Gerlich J, Heinrich S, et al. Association of household cleaning agents and disinfectants with asthma in young German adults. Occup. Environ. Med. 2017;74:684-690.

[8] Le Moual N, Varraso R, Siroux V, et al. Domestic use of cleaning sprays and asthma activity in females. Eur Respir J. 2012;40:1381-1389.

[9] Le Moual N, Rava M, Siroux V, et al. Use of household cleaning products, exhaled nitric oxide and lung function in females. Eur Respir J. 2014;44:816-818.

[10] Matulonga B, Rava M, Siroux V, et al. Women using bleach for home cleaning are at increased risk of non-allergic asthma. Respir. Med. 2016;117:264-271.

[11] Vandenplas O, Wiszniewska M, Raulf M, et al. EAACI position paper: Irritant-induced asthma. Allergy. 2014;69:1141-1153.

[12] Tarlo SM, Lemiere C. Occupational asthma. N. Engl. J. Med. 2014;370:640-649.

[13] Dumas O, Matran R, Zerimech F, et al. Occupational exposures and fluorescent oxidation products in 723 adults of the EGEA study. Eur Respir J. 2015;46:258-261.

[14] De Matteis S, Jarvis D, Hutchings S, et al. Occupations associated with COPD risk in the large population-based UK Biobank cohort study. Occup. Environ. Med. 2016;73:378-384.

[15] Medina-Ramón M, Zock JP, Kogevinas M, et al. Asthma, chronic bronchitis, and exposure to irritant agents in occupational domestic cleaning: a nested case-control study. Occup Env. Med. 2005;62:598-606.

[16] Van den Borre L, Deboosere P. Health risks in the cleaning industry: a Belgian censuslinked mortality study (1991-2011). Int. Arch. Occup. Environ. Health. 2018;91:1321.

[17] Dumas O, Varraso R, Boggs KM, et al. Association of Occupational Exposure to Disinfectants With Incidence of Chronic Obstructive Pulmonary Disease Among US Female Nurses. JAMA Netw. Open. 2019;2:e1913563.

[18] Svanes Ø, Bertelsen RJ, Lygre S, et al. Cleaning at Home and at Work in Relation to Lung Function Decline and Airway Obstruction. Am J Respir Crit Care Med. 2018;197:1157-1163.

[19] Cummings KJ, Virji MA. The Long-Term Effects of Cleaning on the Lungs. Am. J. Respir. Crit. Care Med. 2018;197:1099-1101.

[20] Henderson J, Sherriff A, Farrow A, et al. Household chemicals, persistent wheezing 
and lung function: effect modification by atopy? Eur. Respir. J. 2008;31:547-554.

[21] Casas L, Zock JP, Carsin AE, et al. The use of household cleaning products during pregnancy and lower respiratory tract infections and wheezing during early life. Int. J. Public Health. 2013;58:757-764.

[22] Herr M, Just J, Nikasinovic L, et al. Influence of host and environmental factors on wheezing severity in infants: Findings from the PARIS birth cohort. Clin. Exp. Allergy. 2012;42:275-283.

[23] Mikeš O, Vrbová M, Klánová J, et al. Early-life exposure to household chemicals and wheezing in children. Sci. Total Environ. 2019;663:418-425.

[24] Casas L, Zock J-P, Torrent M, et al. Use of household cleaning products, exhaled nitric oxide and lung function in children. Eur. Respir. J. 2013;42:1412-1415.

[25] Bukalasa JS, Brunekreef B, Koppelman GH, et al. Use of cleaning agents at home and respiratory and allergic symptoms in adolescents: The PIAMA birth cohort study. Environ. Int. 2019;128:63-69.

[26] Wei W, Boumier J, Wyart G, et al. Cleaning practices and cleaning products in nurseries and schools: to what extent can they impact indoor air quality? Indoor Air. 2016;26:517-525.

[27] Bédard A, Varraso R, Sanchez M, et al. Cleaning sprays, household help and asthma among elderly women. Respir. Med. 2014;108:171-180.

[28] Quinot C, Amsellem-Dubourget S, Temam S, et al. Development of a bar code-based exposure assessment method to evaluate occupational exposure to disinfectants and cleaning products: A pilot study. Occup. Environ. Med. 2018;75:668-674.

[29] Ioannou S, Andrianou XD, Charisiadis P, et al. Biomarkers of end of shift exposure to disinfection byproducts in nurses. J. Environ. Sci. 2017;58:217-223.

[30] Marbac M, Sedki M, Boutron-Ruault MC, et al. Patterns of cleaning product exposures using a novel clustering approach for data with correlated variables. Ann. Epidemiol. 2018;28:563-569.e6.

[31] Su FC, Friesen MC, Humann M, et al. Clustering asthma symptoms and cleaning and disinfecting activities and evaluating their associations among healthcare workers. Int. J. Hyg. Environ. Health. 2019;222:873-883.

[32] Agier L, Portengen L, Chadeau-Hyam M, et al. A Systematic Comparison of Linear Regression-Based Statistical Methods to Assess Exposome-Health Associations. Environ. Health Perspect. 2016;124:1848-1856.

[33] Dumas O, Le Moual N, Siroux V, et al. Work related asthma. A causal analysis controlling the healthy worker effect. Occup Env. Med. 2013;70:603-610.

[34] Wang M, Tan G, Eljaszewicz A, et al. Laundry detergents and detergent residue after rinsing directly disrupt tight junction barrier integrity in human bronchial epithelial cells. J. Allergy Clin. Immunol. 2019;143:1892-1903.

[35] Andrianjafimasy M, Zerimech F, Akiki Z, et al. Oxidative stress biomarkers and asthma characteristics in adults of the EGEA study. Eur Respir J. 2017;50:1701193.

[36] Tun MH, Tun HM, Mahoney JJ, et al. Postnatal exposure to household disinfectants, infant gut microbiota and subsequent risk of overweight in children. CMAJ. 2018;190:E1097-E1107.

[37] Scherzer R, Grayson MH. Heterogeneity and the origins of asthma. Ann. Allergy, Asthma Immunol. 2018;121:400-405.

[38] Martinez FD, Guerra S. Early Origins of Asthma: Role of Microbial Dysbiosis and Metabolic Dysfunction. Am. J. Respir. Crit. Care Med. 2018;197:573-579.

[39] Van Der Plaat DA, De Jong K, De Vries M, et al. Occupational exposure to pesticides is associated with differential DNA methylation. Occup. Environ. Med. 2018;75:427435. 